\section{Nitrogen Level and Form Affect Taro Growth and Nutrition}

\author{
N.W. Osorio ${ }^{1}$, X. Shuai, S. Miyasaka, B. Wang, R.L. Shirey, and \\ W.J. Wigmore \\ Department of Tropical Plant and Soil Sciences, 3190 Maile Way, University \\ of Hawaii, Honolulu, HI 96822
}

Additional index words. Colocasia esculenta, nitrate, ammonium, hydroponics, chlorophyll

\begin{abstract}
Nitrogen (N) is often the most limiting mineral nutrient for taro growth. Two experiments were carried out under hydroponics conditions to determine the effects of varying solution $\mathbf{N}$ levels and $\mathbf{N}$ form on taro (Colocasia esculenta $\mathrm{L}$. Schott cv. Bun Long) growth and foliar nutrient concentrations for $\mathbf{4 2}$ days. In the first experiment, taro plants were grown at six $\mathrm{NH}_{4} \mathrm{NO}_{3}$ levels $(0,0.25,0.5,1.0,2.0$, and $4.0 \mathrm{~mm} \mathrm{~N})$. In the second experiment, taro plants were grown at a total $\mathrm{N}$ level of $3 \mathrm{~mm}$ with five nitrate $\left(\mathrm{NO}_{3}^{-}\right)$: ammonium $\left(\mathrm{NH}_{4}^{+}\right)$percent molar ratios $(100: 0,75: 25,50: 50,25: 75$, and 0:100). In the $\mathbf{N}$ level experiment, dry matter and leaf area increased up to $2 \mathrm{~mm} N$ and then decreased at the highest $\mathrm{N}$ level. The reduced growth of taro at the highest $\mathrm{N}$ level was attributed in part to a high $\mathrm{NH}_{4}{ }^{+}$level that reduced uptake or translocation of cations, such as $\mathrm{Ca}^{2+}, \mathrm{Mg}^{2+}$, and $\mathrm{Mn}^{2+}$. Nitrogen concentration in leaf blades increased with increasing $\mathbf{N}$ levels. The critical foliar $\mathbf{N}$ concentration that coincided with $95 \%$ of maximum growth based on a quadratic model was $40.4 \mathrm{~g} \cdot \mathrm{kg}^{-1}$ (dry weight basis). In the $\mathrm{N}$ form experiment, $\mathrm{NO}_{3}{ }^{-}: \mathrm{NH}_{4}{ }^{+}$ratios of $75: 25$ or 100:0 favored greater plant growth compared to other treatments. Taro plants grown in $\mathrm{NH}_{4}{ }^{+}$-rich solutions drastically acidified the solution $\mathrm{pH}$, and had retarded growth and smaller leaf area compared to those grown in $\mathrm{NO}_{3}^{-}$-rich solutions.
\end{abstract}

Taro is a crop commonly cultivated in the tropics, especially in the Pacific basin, where the leaves are consumed as vegetable and corms as staple (De la Pena and Plucknett, 1972). In highly weathered soils, one of the most important constraining production factors is nitrogen $(\mathrm{N})$ deficiency (Sanchez and Logan, 1992). Dryland and wetland taro positively responded to $\mathrm{N}$ fertilization (De La Pena and Plucknett, 1972; Manrique, 1994; Silva et al., 1990). Plant growth, foliar N concentration, and yield increased as a result of $\mathrm{N}$ application with a maximum yield at $\mathrm{N}$ rates of 560 and $1120 \mathrm{~kg} \cdot \mathrm{ha}^{-1}$ for upland and lowland conditions, respectively.

In well-aerated, warm, nonacidic soils, $\mathrm{NO}_{3}{ }^{-}$is the predominant $\mathrm{N}$ form present in the soil solution due to the activity of nitrifying bacteria (Layzell, 1990). Nitrate levels in soil solution typically range from 0.8 to 2.4 mм (Barber, 1995), while $\mathrm{NH}_{4}^{+}$is usually below $1.0 \mathrm{~mm}$ (Marschner, 1995). In acidic or

Received for publication 4 Sept. 2001. Accepted for publication 2 Apr. 2002. Univ. of Hawaii, College of Tropical Agriculture and Human Resources, Journal Series No. 4643.We thank Russell Yost and Hector Valenzuela of the Univ. of Hawaii for reviewing this manuscript. Mention of a product or trade name does not constitute a guarantee or warranty of the product by the Univ. of Hawaii, nor an endorsement over similar products not mentioned.

${ }^{1}$ N.W.O is affiliated with the National Univ. of Colombia at Medellin and currently is studying in the Univ. of Hawaii under a scholarship awarded by COLCIENCIAS-BID. Address correspondence to: N.W. Osorio, National Univ. of Colombia, A.A. 3840 Medellin, Colombia. E-mail address: nwosorio@perseus.unalmed.edu.co flooded soils, in which the activity of nitrifying bacteria is reduced, $\mathrm{NH}_{4}{ }^{+}$is the predominant $\mathrm{N}$ form present (Layzell, 1990). Due to the requirement for charge balance when $\mathrm{N}$ is absorbed as $\mathrm{NO}_{3}^{-}$, the rhizosphere is alkalinized, but when plants absorb $\mathrm{NH}_{4}{ }^{+}$, the rhizosphere is acidified (Marschner and Romheld, 1983). Such soil pH changes could affect microbiological activity and pathogenic relationships with soil microorganisms (Osuna et al., 1991). The form of $\mathrm{N}$ supply plays a key role in the cation-anion relationships in plants, since both $\mathrm{NH}_{4}{ }^{+}$and $\mathrm{NO}_{3}{ }^{-}$represent $\approx 70 \%$ to $80 \%$ of the cations and anions absorbed by plants. At low $\mathrm{N}$ concentrations in nutrient solution the growth differences between plants supplied with $\mathrm{NH}_{4}{ }^{+}$ or $\mathrm{NO}_{3}{ }^{-}$are small, however, with increasing external $\mathrm{N}$ concentrations, the advantage of $\mathrm{NO}_{3}{ }^{-}$as sole source of $\mathrm{N}$ increases for most plants (Gerendas and Sattelmacher, 1990).

The response to $\mathrm{N}$ form varies with plant species. For example, Scoggins and Mills (1998) recently found that the growth and nutritional status of poinsettia (Euphorbia pulcherrima Willd. ex Klotzsch) grown in nutrient solution was favored by high $\mathrm{NO}_{3}{ }^{-}$concentrations, whereas $\mathrm{NH}_{4}{ }^{+}$had deleterious effects. Similar results were obtained in Vinca sp. (Thomas and Latimer, 1995), wheat (Triticum aestivum) (Xu et al., 1992), cucumber (Cucumus sativus) (Heuer, 1991), and bell pepper (Capsicum annuum) (Marti and Mills, 1991) growth in nutrient solution. However, some plants prefer $\mathrm{NH}_{4}{ }^{+}$as the major source of N. For example, rice (Oryza sativa L.) (Magalhaes and Huber, 1991) and maize (Zea mays L.) (Anderson et al., 1991). In general, the best results are obtained when there is a mix of both $\mathrm{N}$ forms in solution (Errebhi and Wilcox, 1990).
Given the adaptation of taro to flooded conditions (De la Pena and Plucknett, 1972) we predicted that taro would prefer $\mathrm{NH}_{4}{ }^{+}$as $\mathrm{N}$-source. To our knowledge, there were no previous studies conducted on $\mathrm{N}$ form effects on taro. The objectives of these experiments were to determine the effects of different $\mathrm{N}$ levels and $\mathrm{NO}_{3}^{-}: \mathrm{NH}_{4}{ }^{+}$ratios on growth and foliar nutrient concentration of taro seedlings grown in nutrient solution.

\section{Materials and Methods}

Two experiments were conducted in greenhouses in the Univ. of Hawaii at Manoa $\left(21^{\circ} 19^{\prime} \mathrm{N}, 157^{\circ} 58^{\prime} \mathrm{W}\right)$. In both experiments, propagating materials $(0.5 \mathrm{~cm}$ of upper corm plus $30 \mathrm{~cm}$ of lower petiole) of taro cv. Bun long were grown for a week in a 1 perlite : 1 vermiculite medium (v/v). Rooted taro propagating materials were washed to remove adhered substrate from roots and then selected for uniform size within replicates. One seedling was placed per pot on a plastic rack located directly above $10 \mathrm{~L}$ of an aerated nutrient solution in polyethylene buckets following the procedure of Miyasaka et al. (1993). During the first week after transplanting, some plants that exhibited poor growth were replaced.

$N$ level experiment. This experiment was carried out from 28 Jan. to 11 Mar. 1997 with six $\mathrm{N}$ levels $(0,0.25,0.5,1.0,2.0$, and $4.0 \mathrm{~mm}$ ) as $\mathrm{NH}_{4} \mathrm{NO}_{3}$ in the nutrient solution. The basal nutrient solution was a modified Steinberg solution (Miyasaka et al., 1993) that had the following composition (mM): $0.2 \mathrm{P}, 1.2 \mathrm{~K}, 1 \mathrm{Ca}, 0.4 \mathrm{Mg}$, and $0.8 \mathrm{~S}$. Micronutrients were supplied in the following concentrations $(\mu \mathrm{M}): 2 \mathrm{Mn}, 6, \mathrm{~B}, 1 \mathrm{Zn}$, $0.5 \mathrm{Cu}, 0.1 \mathrm{Mo}$, and $10 \mathrm{Fe}$. The nutrient sources used were analytical grade chemicals: $\mathrm{Ca}\left(\mathrm{NO}_{3}\right)_{2} \cdot 4 \mathrm{H}_{2} \mathrm{O}, \quad \mathrm{NH}_{4} \mathrm{Cl}$, $\mathrm{MgSO}_{4} \cdot 7 \mathrm{H}_{2} \mathrm{O}, \mathrm{K}_{2} \mathrm{SO}_{4}, \mathrm{~K}_{2} \mathrm{HPO}_{4}, \mathrm{CaCl}_{2}$, $\mathrm{MnSO}_{4} \cdot \mathrm{H}_{2} \mathrm{O}, \mathrm{ZnSO}_{4} \cdot 7 \mathrm{H}_{2} \mathrm{O}, \mathrm{CuSO}_{4} \cdot 5 \mathrm{H}_{2} \mathrm{O}$, $\mathrm{H}_{3} \mathrm{BO}_{3}, \mathrm{H}_{2} \mathrm{MoO}_{4} \cdot \mathrm{H}_{2} \mathrm{O}, \mathrm{KCl}$, and Fe-ethylene diamine $\mathrm{Dl}$ o-hydroxyphenyl acetic acid. The $\mathrm{pH}$ of the solution was adjusted to 6.0 using $0.25 \mathrm{~mm}$ of a buffer solution MES (2-[Nmorpholino]ethanesulfonic acid) (Miyasaka et al., 1988) and $\mathrm{NaOH}$.

$N$ form experiment. This experiment was carried out from 28 Jan. to 11 Mar. 1999, and the treatments consisted of five $\mathrm{NO}_{3}{ }^{-}: \mathrm{NH}_{4}{ }^{+}$ ratios $(100: 0,75: 25,50: 50,25: 75$, and $0: 100)$ at a total $\mathrm{N}$ concentration of $3 \mathrm{~mm}$. The basal nutrient solution had a $\mathrm{pH}$ of 6.4 with the following macronutrient composition (mM): 0.13 $\mathrm{P}, 0.43 \mathrm{~K}, 0.35 \mathrm{Ca}, 0.29 \mathrm{Mg}, 0.14 \mathrm{~S}$, and 0.04 $\mathrm{Na}$. Macronutrient levels were reduced from the first trial to provide adequate cation levels but to minimize $\mathrm{Cl}$ concentrations to below the $4.9 \mathrm{~mm}$ level that causes salinity stress in taro (Hill et al., 1998). Micronutrients were supplied in concentrations similar to those used in the first experiment. Solution $\mathrm{pH}$ was buffered with $0.25 \mathrm{~mm}$ MES as described for the first experiment.

Sampling and analysis. Solution $\mathrm{pH}$ was measured weekly throughout the course of both experiments. Nondestructive measurements of chlorophyll were taken using a chlorophyll- 
meter (SPAD-502; Minolta, Tokyo) (MacKown and Sutton, 1998) at 28 and $42 \mathrm{~d}$ after transplanting. Plants were removed from the nutrient solution $42 \mathrm{~d}$ after transplanting, washed in deionized water, and divided into roots, corms, petioles, and leaf blades. Leaf lamina area was determined with a leaf area meter (LI-3100; LI-COR, Lincoln, Nebr.). All plant parts were subsequently dried in a forced air oven at $60{ }^{\circ} \mathrm{C}$ to constant weight, and then weighed. Leaves were passed through a 1-mm mesh and then ashed in a muffle furnace and analyzed for $\mathrm{Ca}, \mathrm{Mg}, \mathrm{K}, \mathrm{P}, \mathrm{Mn}, \mathrm{Zn}, \mathrm{Cu}, \mathrm{Fe}$, and $\mathrm{B}$ using an inductively coupled plasma spectrometer (model 6500; Perkin-Elmer, Norwalk, Conn.) (Isaac and Johnson, 1998). Total $\mathrm{N}$ was determined by a micro-Kjeldahl method (Nelson and Sommers, 1972).

In each experiment, a completely randomized design with three replicates was used. Data were subjected to analysis of variance, trends, and regression to identify significant treatment effects $(P \leq 0.05)$ (Little and Hills, 1978; Neter et al., 1996) using SAS (SAS Institute, Cary, N.C.) program. In the second experiment, the molar ratio of $\mathrm{NH}_{4}^{+}$, expressed as percentage $(0-100)$, was used as the independent variable for the regression analysis.

\section{Results}

$N$ level experiment. At $0,0.25$, and $0.5 \mathrm{~mm}$ $\mathrm{N}$, leaf blades appeared chlorotic due to $\mathrm{N}$ deficiency. Increasing solution $\mathrm{N}$ levels increased and then significantly decreased total plant dry (Table 1). A quadratic model fit the data well for total dry weight (TDW) $($ TDW $=7.99+$ $\left.7.29 N s-1.65 N s^{2} ; r^{2}=0.64\right)$, where $N s$ is the concentration of $\mathrm{N}$ in solution. Increasing solution $\mathrm{N}$ levels significantly increased foliar $\mathrm{N}$ concentration (Table 1).

There was a significant quadratic relationship between leaf blade $\mathrm{N}$ concentration and total plant dry matter (Fig. 1). The critical foliar N concentration corresponding to $95 \%$ of the maximum growth determined by this quadratic model was $40.4 \mathrm{~g} \cdot \mathrm{kg}^{-1}$ leaf tissue.

Leaf blade $\mathrm{Ca}, \mathrm{Mg}$, and $\mathrm{Mn}$ concentrations were negatively affected by increasing solution N levels $(P \leq 0.05)$ (Table 1$)$. Foliar $\mathrm{P}, \mathrm{K}, \mathrm{Na}, \mathrm{Fe}, \mathrm{Cu}, \mathrm{Zn}$, and $\mathrm{B}$ concentrations were unaffected by $\mathrm{N}$ treatments. Total $\mathrm{N}, \mathrm{P}$, and $\mathrm{K}$ contents were significantly $(P \leq 0.05)$ higher when $\mathrm{N}$ concentration in the solution increased. Other nutrients exhibited a similar tendency but there were no significant differences among treatments.

The initial solution $\mathrm{pH}$ was 6.0 , but after 4 weeks of growth it dropped to $\approx 3.0$ at 0.0 to 0.5 $\mathrm{mm} \mathrm{N}$, and to $\approx 2.5$ at the 1.0 to $4.0 \mathrm{~mm} \mathrm{~N}$ levels. Solutions were changed and $\mathrm{pH}$ readjusted to 6.0 at 4 weeks. At harvesting, the solution $\mathrm{pH}$ was 3.4 in all $\mathrm{N}$ concentrations except in the zero-N level, which had a $\mathrm{pH}$ of 7.3.

Nitrogen form experiment. Plants grown in a solution rich in $\mathrm{NO}_{3}{ }^{-}$(100:0 and 75:25) had significantly greater dry weights than those grown in a solution rich in $\mathrm{NH}_{4}{ }^{+}(25$ : 75 and $0: 100$ ) (Fig. 2). There were significant decreases in the dry weight of roots (DWR) $(P \leq 0.0001)$, petioles (DWP) $(P \leq 0.0001)$, and leaf blades (DWL) $(P \leq 0.0001)$ with an increasing proportion of $\mathrm{NH}_{4}{ }^{+}$. Quadratic regression models were significant $(P<0.05)$ and their coefficients of determination $\left(r^{2}\right)$ were above 0.80 (Fig. 2). Corm dry weights were not significantly affected by treatments (data not shown), possibly due to their high coefficient of variation $(32.4 \%)$ or to the short duration of growth which apparently was not sufficient for the formation of new corm material.

Increasing the proportion of $\mathrm{NH}_{4}^{+}$significantly decreased leaf area $(P \leq 0.001$, Fig. 3). A quadratic model fitted the data well $\left(P \leq 0.0001 ; r^{2}=0.84\right)$. The highest leaf area was obtained at $\mathrm{NO}_{3}^{-}: \mathrm{NH}_{4}{ }^{+}$ratios of $75: 25$ or 100:0, with no significant differences between these two treatments. The treatment with 100 $\% \mathrm{NH}_{4}{ }^{+}$had the lowest leaf area.

At $28 \mathrm{~d}$ after transplanting, significant differences $(P \leq 0.05)$ in chlorophyll content were detected among treatments, with the lowest value found at the $75: 25$ treatment and the highest value at the 0:100 treatment $\left(\mathrm{NH}_{4}{ }^{+}-\right.$ rich solution) (Table 2). Since these results were opposite to those obtained for DWL, they suggest that the inhibition of leaf expansion was greater than the reduction in the content of chlorophyll; similar to the dilution effect reported for P deficiency in some crops (Rao and Terry, 1989). At harvest, there were no significant differences among treatments with respect to chlorophyll content (Table 2).

An increasing proportion of $\mathrm{NH}_{4}^{+}$significantly increased leaf concentrations of $\mathrm{N}(P$ $\leq 0.05)$ and $\mathrm{B}(P \leq 0.01)$ (Table 2$)$. Other nutrient concentrations in leaf blades were not significantly affected. The treatment with $100 \%$ $\mathrm{NH}_{4}{ }^{+}(0: 100)$ had a significantly greater foliar $\mathrm{N}$ concentration compared to other treatments.
The lowest $\mathrm{N}$ concentrations in leaf blades were obtained with $\mathrm{NO}_{3}{ }^{-}$-rich treatments (75: 25 and 100:0); however, the total amount of $\mathrm{N}$ accumulated in leaf blades was significantly greater in plants fertilized with $\mathrm{NO}_{3}{ }^{-}$(data not shown). A similar situation was observed with B (Table 2), which indicated that growth was stunted to a greater degree relative to the uptake and translocation of N and B (reverse growth dilution effect, see Jarrell and Beverly, 1986). The $\mathrm{NO}_{3}{ }^{-}$-rich treatments $(75: 25$ and 100:0) also resulted in higher total contents of all other nutrients in leaf blades compared to the $\mathrm{NH}_{4}{ }^{+}-$ rich treatments (data not shown).

In this experiment, there was also a strong decline of the solution $\mathrm{pH}$ in the $\mathrm{NH}_{4}{ }^{+}$-rich treatments despite buffering and changes of nutrient solution. Solution $\mathrm{pH}$ values decreased to as low as 3.1 in the $100 \% \mathrm{NH}_{4}{ }^{+}$solutions.

\section{Discussion}

Total plant dry matter and leaf area increased and then decreased with increasing $\mathrm{NH}_{4} \mathrm{NO}_{3}$ levels in the first experiment (Table 1). The highest solution $\mathrm{N}$ level of $4 \mathrm{~mm} \mathrm{~N}$ had a negative effect on plant growth. Similar results were found by Miyasaka (1979) in which higher levels of $\mathrm{NH}_{4} \mathrm{NO}_{3}$ depressed yield and biomass of taro cv. Lehua Maoli grown for 6 months in solution culture.

Such an inhibitory effect of increased $\mathrm{NH}_{4} \mathrm{NO}_{3}$ levels seems to be associated with a reduction in the foliar concentration of certain cations, particularly $\mathrm{Ca}, \mathrm{Mg}$, and $\mathrm{Mn}$ (Table 1). Possibly, uptake of $\mathrm{NH}_{4}{ }^{+}$interfered with the absorption and translocation of cations (Bernardo et al., 1984; Hamlin et al., 1999; Traore and Maranville, 1999). The critical foliar concentration of $\mathrm{Ca}$ in 49 day-old taro cv. Lehua Maoli was $4.0 \mathrm{~g} \cdot \mathrm{kg}^{-1}$ (Miyasaka, 1979). The critical concentration of $\mathrm{Mg}$ in 33 day-old taro cv. Bun Long was $1.4 \mathrm{~g} \cdot \mathrm{kg}^{-1}$ (Austin et al., 1994). The critical foliar concentration of $\mathrm{Mn}$ in taro cultivars Niue and Alafua Sunrise was $21 \mathrm{mg} \cdot \mathrm{kg}^{-1}$ (O'Sullivan et al., 1995). Based on these critical foliar concentrations, the tissue levels of $\mathrm{Ca}, \mathrm{Mg}$, and $\mathrm{Mn}$ were adequate but they had a tendency to decrease with the increases in solution $\mathrm{NH}_{4}^{+}$concentration. The foliar concentrations of other cations also appear to be above the critical concentrations (Ares et al., 1996; O'Sullivan et al., 1995).

Based on a quadratic model, the critical foliar $\mathrm{N}$ concentration that corresponded to

Table 1. Effects of the solution N concentration on the mean total dry weight (TDW), leaf area (LA), and nutrient concentration of the leaf blades of taro 'Bun Long' plants.

\begin{tabular}{|c|c|c|c|c|c|c|c|c|c|c|c|c|c|}
\hline$\overline{\mathrm{N} \text { solution }(\mathrm{mm})}$ & TDW (g/plant) & $\mathrm{LA}\left(\mathrm{cm}^{2} / \mathrm{leaf}\right)$ & $\mathrm{N}$ & $\mathrm{P}$ & $\mathrm{K}$ & $\mathrm{Ca}$ & $\mathrm{Mg}$ & $\mathrm{Na}$ & $\mathrm{Mn}$ & $\mathrm{Fe}$ & $\mathrm{Cu}$ & $\mathrm{Zn}$ & $\mathrm{B}$ \\
\hline & & & --1 & -- & -- & $-(\mathrm{g} \cdot \mathrm{k}$ & -- & -- & -- & -- & $(\mathrm{mg} \cdot \mathrm{kg}$ & -- & -- \\
\hline 0.0 & 8.0 & 129 & 29 & 4.0 & 36 & 24 & 7.5 & 2.7 & 564 & 317 & 19 & 56 & 117 \\
\hline 0.25 & 8.1 & 393 & 35 & 5.2 & 37 & 19 & 4.5 & 0.7 & 459 & 129 & 11 & 35 & 58 \\
\hline 0.5 & 12.5 & 487 & 35 & 5.1 & 42 & 19 & 4.1 & 0.9 & 477 & 215 & 11 & 33 & 58 \\
\hline 1.0 & 14.9 & 739 & 39 & 5.3 & 44 & 16 & 3.7 & 0.7 & 200 & 119 & 10 & 33 & 57 \\
\hline 2.0 & 14.3 & 636 & 47 & 5.2 & 46 & 11 & 3.1 & 0.6 & 117 & 79 & 15 & 39 & 40 \\
\hline 4.0 & 10.9 & 648 & 55 & 6.1 & 46 & 13 & 3.5 & 0.7 & 125 & 133 & 22 & 48 & 57 \\
\hline Trend analysis $\mathrm{z}$ & Q & NS & Q & NS & NS & $\mathrm{L}$ & Q & NS & Q & NS & NS & NS & NS \\
\hline$(P$-value $)$ & $<0.01$ & & $<0.01$ & & & $<0.0$ & $<0.05$ & & $<0.01$ & & & & \\
\hline
\end{tabular}

${ }^{2} \mathrm{~L}=$ linear; $\mathrm{Q}=$ quadratic; TDW $=7.99+7.29 N s-1.65 N s^{2}\left(r^{2}=0.64\right), \mathrm{N}=30.9+10.91 N s-1.05 N s^{2}\left(r^{2}=0.93\right), \mathrm{Ca}=20.39-2.46 N s$ $\left(r^{2}=0.41\right), \mathrm{Mg}=6.22-3.09 N s+0.61 N s^{2}\left(r^{2}=0.47\right)$, and $\mathrm{Mn}=571-373 N s+65.5 N s^{2}\left(r^{2}=0.77\right)$, where, $N s=$ concentration of $\mathrm{N}$ in the solution.

Ns Nonsignificant. 


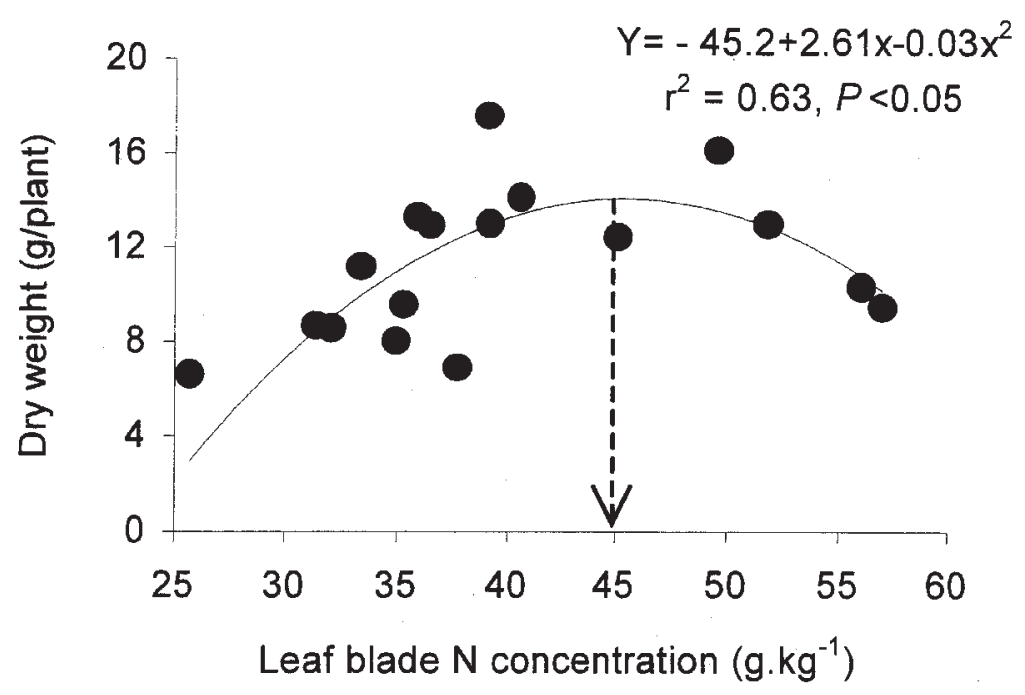

Fig. 1. Quadratic relationship between 'Bun Long' taro plant dry weight and $\mathrm{N}$ concentration in leaf blades. The arrow indicates leaf blade $\mathrm{N}$ concentration at $100 \%$ of maximum plant dry weight.

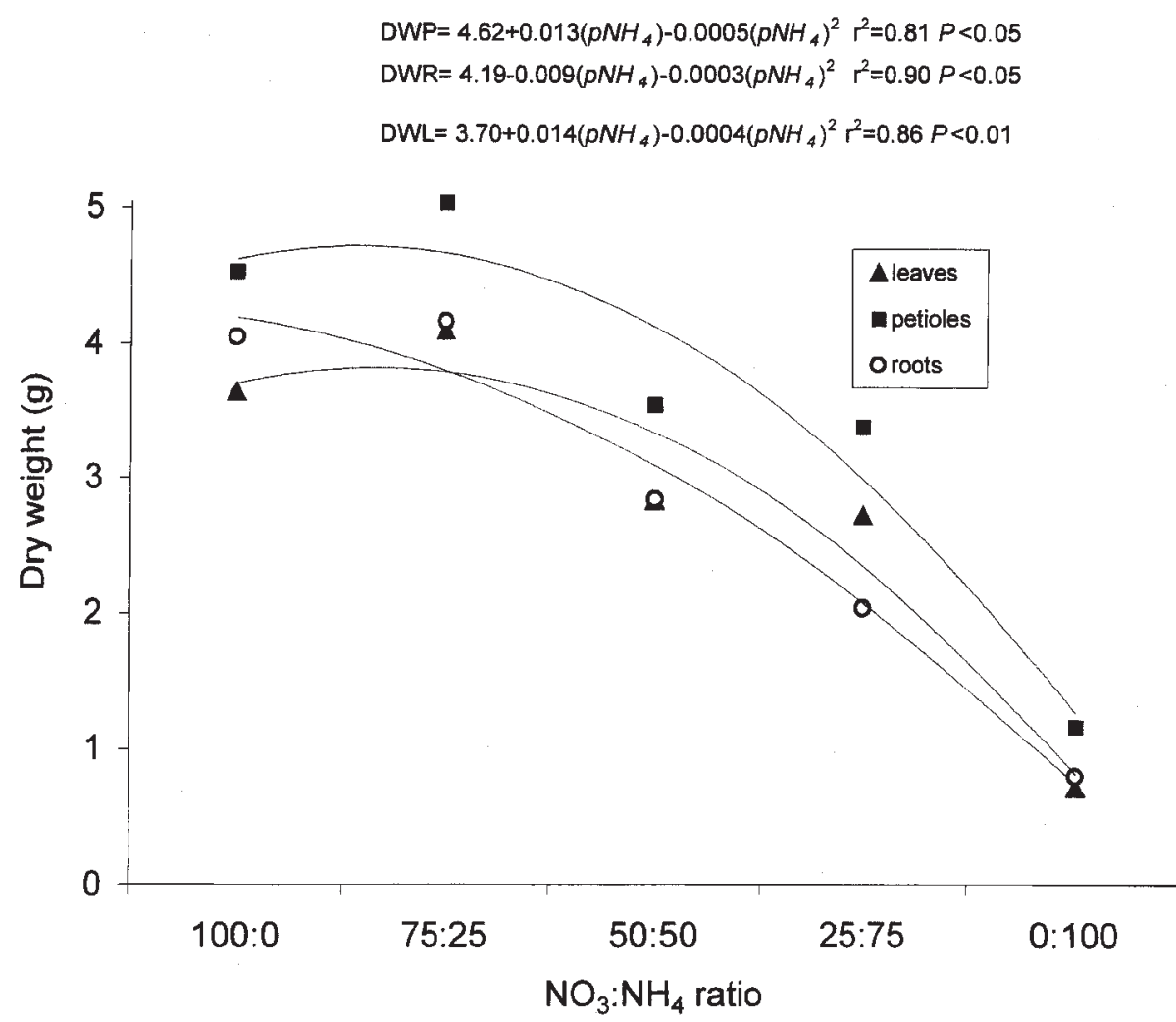

Fig. 2. Effects of the $\mathrm{N}$ form ratio on the dry weight (DW) of 'Bun Long' taro plant parts ( $\mathrm{P}=$ petioles; $\mathrm{R}$ $=$ roots; $\mathrm{L}=$ leaf blades $)\left(\mathrm{pNH}_{4}=\right.$ molar ratio of $\mathrm{NH}_{4}{ }^{+}$expressed as percentage, $\left.0-100\right)$.
95\% of maximum growth was $40.4 \mathrm{~g} \cdot \mathrm{kg}^{-1}$ (dry weight basis). Our results are consistent with the leaf $\mathrm{N}$ critical level of $37 \mathrm{~g} \cdot \mathrm{kg}^{-1}$ proposed by O'Sullivan et al. (1995) for the second youngest fully matured leaf of cultivars Niue and Alafua Sunrise. Also, Silva et al. (1990) proposed an adequate range of $42-46 \mathrm{~g} \cdot \mathrm{kg}^{-1}$.

In the $\mathrm{N}$ form experiment, the best growth and leaf nutrient accumulation was observed when taro plants were grown in a solution with $\mathrm{NO}_{3}{ }^{-}$as the predominant $\mathrm{N}$ form. The best treatments were solutions containing either a proportion of $75 \% \mathrm{NO}_{3}{ }^{-}$and $25 \% \mathrm{NH}_{4}{ }^{+}$or $100 \% \mathrm{NO}_{3}^{-}$. Plants are able to store $\mathrm{NO}_{3}{ }^{-}$in root cell vacuoles without detrimental effects and without the immediate necessity of metabolism in the roots (Layzell, 1990). In contrast, $\mathrm{NH}_{4}{ }^{+}$ is quite toxic even at low concentrations and must be incorporated into organic compounds in roots, requiring an abundance of carbon skeletons (Layzell, 1990; Marschner, 1995). In our experiment, root growth was inhibited when taro plants were supplied with the $\mathrm{NH}_{4}{ }^{+}$-rich solutions (Fig. 2).

In $\mathrm{NH}_{4}{ }^{+}$-fertilized plants, the $\mathrm{pH}$ in the cytoplasm decreases during $\mathrm{NH}_{4}{ }^{+}$assimilation and must be stabilized by enhanced proton excretion or decarboxylation of organic acids for charge balance (Davies, 1986). In our experiments, high levels of $\mathrm{NH}_{4}{ }^{+}$supply (as in the 25:75 and 0:100 treatments) resulted in drastic decline of $\mathrm{pH}$ even in a buffered solution. This decrease in solution $\mathrm{pH}$ could have a deleterious effect on root membranes and nutrient uptake (Logan et al., 1999). At low external pH, net excretion of protons is impaired and cytosolic pH may also fall (Gerendas et al., 1990). Gerendas et al. (1997) suggest that $\mathrm{NH}_{4}{ }^{+}$toxicity may disappear if low $\mathrm{pH}$ is prevented. The $\mathrm{pH}$ changes observed in the solution culture may not happen in clay soils used for flooded crops because the $\mathrm{pH}$ buffer capacity that exhibit these soils (Brady and Weil, 2002).

In contrast, $\mathrm{NO}_{3}{ }^{-}$assimilation has been correlated with an about equimolar production of $\mathrm{OH}^{-}$or consumption of $\mathrm{H}^{+}$(Raven, 1986), and as a consequence, the $\mathrm{pH}$ in the external solution was less affected. When both $\mathrm{NH}_{4}{ }^{+}$and $\mathrm{NO}_{3}{ }^{-}$are supplied, the regulation of the $\mathrm{pH}$ may be achieved by similar rates of $\mathrm{H}^{+}$production $\left(\mathrm{NH}_{4}{ }^{+}\right.$assimilation) and $\mathrm{H}^{+}$consumption $\left(\mathrm{NO}_{3}{ }^{-}\right.$assimilation), again resulting in little change in external solution $\mathrm{pH}$ (Findenegg et al., 1982; Gerandas et al., 1990). This assimilatory process may explain, at least in part, the

Table 2. Effects of $\mathrm{N}$ form ratio on the nutrient concentration and chlorophyll-meter readings in the leaf blades of 'Bun Long' taro plants.

\begin{tabular}{|c|c|c|c|c|c|c|c|c|c|c|c|c|c|}
\hline \multirow[b]{2}{*}{$\mathrm{NO}_{3}: \mathrm{NH}_{4}$ ratio } & \multirow[b]{2}{*}{$\mathrm{N}$} & \multirow[b]{2}{*}{$\mathrm{P}$} & \multirow[b]{2}{*}{$\mathrm{K}$} & \multirow[b]{2}{*}{$\mathrm{Ca}$} & \multirow[b]{2}{*}{$\mathrm{Mg}$} & \multirow[b]{2}{*}{$\mathrm{Na}$} & \multirow[b]{2}{*}{$\mathrm{Mn}$} & \multirow[b]{2}{*}{$\mathrm{Fe}$} & \multirow[b]{2}{*}{$\mathrm{Cu}$} & \multirow[b]{2}{*}{$\mathrm{Zn}$} & \multirow[b]{2}{*}{ B } & \multicolumn{2}{|c|}{ Chlorophyll reading } \\
\hline & & & & & & & & & & & & $28 \mathrm{~d}$ & $42 \mathrm{~d}$ \\
\hline & --- & -- & $-(\mathrm{g}$ & $\left.3^{-1}\right)-$ & -- & -- & -- & --- & $\mathrm{g} \cdot \mathrm{kg}^{-}$ & -- & --- & & \\
\hline 100:0 & 37 & 3.4 & 31 & 20 & 3.6 & 1.7 & 224 & 165 & 47 & 43 & 20 & 42 & 42 \\
\hline $75: 25$ & 38 & 3.3 & 32 & 17 & 3.6 & 1.2 & 215 & 223 & 43 & 44 & 18 & 41 & 44 \\
\hline $50: 50$ & 39 & 3.8 & 37 & 14 & 3.0 & 1.2 & 183 & 192 & 21 & 37 & 17 & 43 & 45 \\
\hline $25: 75$ & 44 & 3.9 & 35 & 11 & 3.3 & 0.9 & 153 & 508 & 14 & 38 & 18 & 47 & 47 \\
\hline $0: 100$ & 63 & 6.2 & 34 & 11 & 3.3 & 1.3 & 200 & 380 & 39 & 42 & 43 & 55 & 51 \\
\hline $\begin{array}{l}\text { Trend analysis }{ }^{\mathrm{z}} \\
(P \text { value })\end{array}$ & $\begin{array}{c}\mathrm{Q} \\
<0.05\end{array}$ & NS & NS & NS & NS & NS & NS & NS & NS & NS & $\begin{array}{c}\mathrm{Q} \\
<0.01\end{array}$ & $\begin{array}{c}\mathrm{L} \\
<0.05\end{array}$ & NS \\
\hline
\end{tabular}




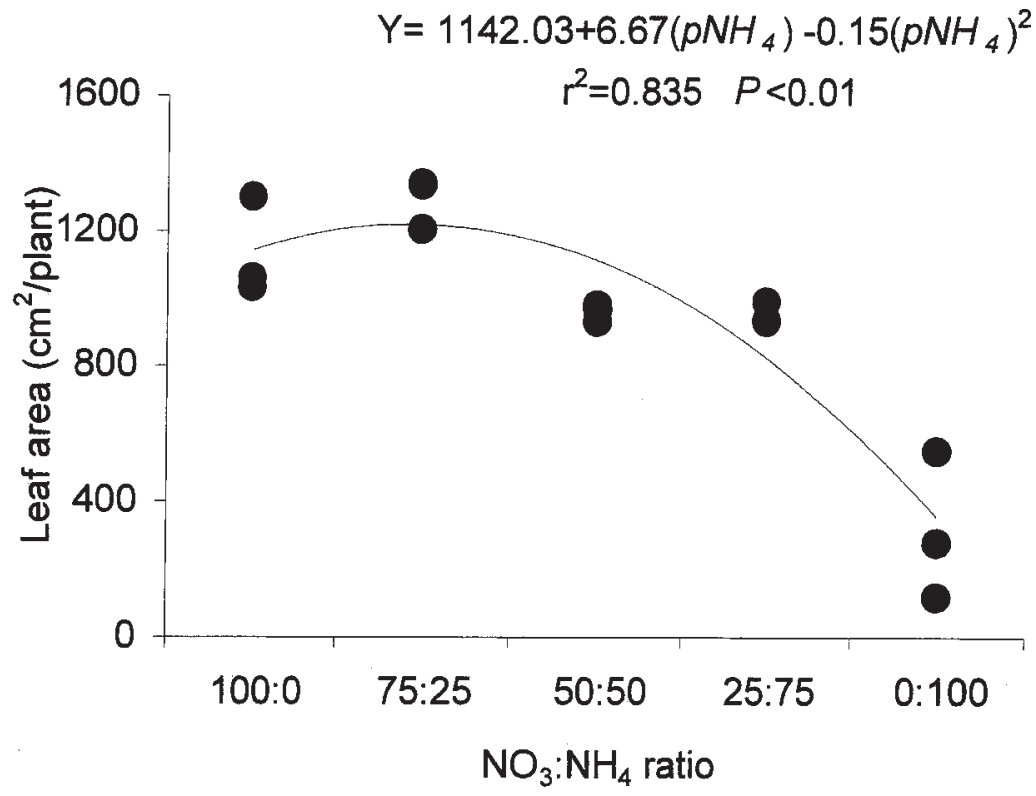

Fig. 3. Effects of $\mathrm{N}$ form ratio on the leaf area of 'Bun Long' taro plants $\left(p N H_{4}=\right.$ molar ratio of $\mathrm{NH}_{4}{ }^{+}$ expressed as percentage, $0-100$ ).

reason why optimal growth and high nutrient accumulation for taro was obtained either with $100 \% \mathrm{NO}_{3}{ }^{-}$or with a mixed supply of both $\mathrm{N}$ forms (75:25 treatment).

The retarded plant growth observed at high $\mathrm{NH}_{4}{ }^{+}$levels in solution may be due, at least in part, to the antagonism between $\mathrm{NH}_{4}{ }^{+}$and cation absorption and translocation (Bernardo et al., 1984; Hamlin et al., 1999). Although significant decreases in foliar concentrations of cations in trial 2 were not found as the proportion of $\mathrm{NH}_{4}^{+}$increased (Table 2), significant decreases in $\mathrm{Ca}, \mathrm{Mg}$, and $\mathrm{Mn}$ concentrations in leaf blades were found as $\mathrm{NH}_{4} \mathrm{NO}_{3}$ levels increased in the experiment 1 (Table 1).

Taro is a plant species well adapted to flooded conditions (De la Pena and Plucknett, 1972; Miyasaka et al., 1993), in which $\mathrm{NH}_{4}^{+}$ is the predominant $\mathrm{N}$ form (Layzell, 1990). Consequently, we expected a higher preference of taro for this $\mathrm{N}$ form, however, under our experimental conditions, taro preferred $\mathrm{NO}_{3}^{-}$.

Ammonium concentration in soil solution rarely exceeds $1 \mathrm{~mm}$ (Marschner, 1995). At low total $\mathrm{N}$ concentrations in the external solution, the growth differences between $\mathrm{NH}_{4}{ }^{+}$and $\mathrm{NO}_{3}{ }^{-}$are small, but with increasing external concentrations the advantage of $\mathrm{NO}_{3}{ }^{-}$as sole source of N increases (Gerendas and Sattelmacher, 1990). In the $\mathrm{N}$ form experiment, taro plants grown in the $\mathrm{NH}_{4}{ }^{+}$rich solutions (50: $50,25: 75$, and $0: 100)$ were exposed to very high concentrations of $\mathrm{NH}_{4}^{+}(1.5,2.25$ and 3 $\mathrm{mm}$, respectively), which appeared to be toxic to taro. Similarly, in the $\mathrm{N}$ level experiment, the $\mathrm{NH}_{4}: \mathrm{NO}_{3}$ ratio was 50:50, resulting in an $\mathrm{NH}_{4}{ }^{+}$level of $2.0 \mathrm{~mm}$ at the highest $\mathrm{N}$ level. It is likely that reduced plant growth observed at the highest total $\mathrm{N}$ level was due to toxic $\mathrm{NH}_{4}{ }^{+}$effect. It is necessary to examine: 1) the effects of $\mathrm{N}$ form on taro growth at a lower total solution $\mathrm{N}$ level; and 2) the interaction between solution $\mathrm{pH}$ and $\mathrm{NH}_{4}^{+}$toxicity effects.

\section{Conclusions}

Total plant dry weight and leaf area of 'Bun long' taro increased with increasing solution $\mathrm{N}$ levels up to $2 \mathrm{~mm}$ and then decreased at $4 \mathrm{~mm}$. At a total solution $\mathrm{N}$ level of $3 \mathrm{~mm}$, taro plants grew best when $\mathrm{NO}_{3}^{-}$was the predominant $\mathrm{N}$ form in nutrient solution (e.g. at $\mathrm{NO}_{3}^{-}: \mathrm{NH}_{4}{ }^{+}$ratio of $75: 25$ or 100:0). The decrease in plant growth at the highest $\mathrm{N}$ level was attributed to a toxic level of $\mathrm{NH}_{4}{ }^{+}$that interfered with cation absorption and translocation. In addition, the decrease in $\mathrm{pH}$ to 3.1 in $\mathrm{NH}_{4}{ }^{+}$-rich solutions could be a contributing factor to $\mathrm{NH}_{4}{ }^{+}$-toxicity.

\section{Literature Cited}

Anderson, D., R.H. Teyker, and A.L. Rayburn. 1991. Nitrogen form effects on early corn root morphology and anatomical development. J. Plant Nutr. 14:1255-1266. Taro response to different iron levels in hydroponic solution. J. Plant Nutr. 19:281-292.

Austin, M.T., M. Constantinides, and S.C. Miyasaka. 1994. Effect of magnesium on early taro growth. Commun. Soil Sci. Plant Anal. 25:2159-2169.

Barber, S.A. 1995. Soil nutrient bioavailability: A mechanistic approach. Wiley, New York.

Bernardo, L.M., R.B. Clark, and J.W. Maranville. 1984. $\mathrm{NO}_{3}^{-} / \mathrm{NH}_{4}{ }^{+}$as a source of $\mathrm{N}$ for corn and their influence on the uptake of other ions. Agron. J. 82:463-467.

Brady, N.C. and R.R. Weil. 2002. The nature and properties of soils. Prentice Hall, Upper Saddle River, N.J.

Davies, D.D. 1986. The fine control of cytosolic pH. Physiol. Plant 67:702-706.

De la Pena, R. and D. Plucknett. 1972. Effects of nitrogen fertilization on the growth, composition and yield of upland and lowland taro (Colocasia esculenta). Expt. Agr. 187-194.

Errebhi, M. and G.E. Wilcox. 1990. Tomato growth and nutrient uptake pattern as influenced by nitrogen form ratio. J. Plant Nutr. 13:1031-1043.
Ares, A., S.G. Hwang, and S.C. Miyasaka. 1996.
Findenegg, G.R., M. Salihu, and N.A. Ali. 1982. Internal self-regulation of $\mathrm{H}^{+}$-ion concentration in acid damaged and healthy plants of Sorghum bicolor (L.) Moench. Proc. $9^{\text {th }}$ Plant Nutr. Coloq. Cmwlth. Agr. Bur., Bucks, U.K., 174-179.

Gerendas, J. and B. Sattelmacher. 1990. Influence of nitrogen form and concentration on growth and ionic balance of tomato and potato, p. 33-37. In: M.L. Van Beusichem (ed.). Plant nutritionphysiology and application. Kluwer Academic Publishers, Dordrecht.

Gerendas, J., R.G. Ratcliffe, and B. Sattelmacher 1990. ${ }^{31} \mathrm{P}$ nuclear magnetic resonance evidence for differences in intracellular $\mathrm{pH}$ in the roots of maize seedlings grown with nitrate or ammonium. J. Plant Physiol. 137:125-128.

Gerendas, J., Z. Zhu, R. Bendixen, R. G. Ratcliffe, and B. Sattelmacher. 1997. Physiological and biochemical processes related to ammonium toxicity in higher plants. Z. Pflanzenernahr. Bodenk. 160:239-251.

Hamlin, R.L., H.A. Mills, and W.N. Randle. 1999. Growth and nutrition of pansy as influenced by $\mathrm{N}$-form ratio and temperature. J. Plant Nutr. 22: $1637-1650$.

Heuer, B. 1991. Growth, photosynthesis and protein content in cucumber plants as affected by supplied nitrogen form. J. Plant Nutr. 14: 363-373.

Hill, S., R. Abaidoo, and S. Miyasaka. 1998. Sodium chloride concentration affects early growth and nutrient accumulation in taro. HortScience 33: $1153-1156$.

Isaac, R.A. and W.C. Johnson. 1998. Elemental determination by inductively coupled plasma-atomic emission spectroscopy, p. 165-170. In: Y.P. Kalra (ed.). Handbook of reference methods for plant analysis. CRC Press, Boca Raton.

Jarrell, W.M. and R.B. Beverley. 1986. The dilution effect in plant nutrition studies. Adv. Agron. 34: 197-224.

Layzell, D.B. 1990. $\mathrm{N}_{2}$ fixation, $\mathrm{NO}_{3}$ reduction, and $\mathrm{NH}_{4}$ assimilation, p. 389-406. In: Dennis, D.T., and D.H. Turpin (eds.). Plant physiology, biochemistry, and molecular biology. Wiley, New York.

Little, T.M. and F.J. Hills. 1978. Agriculture experimentation. Design and analysis. Wiley, New York.

Logan, K., R. Thomas, and J. Raven. 1999. Hydrogen ion production and ammonium uptake by two tropical forage grasses. J. Plant Nutr. 22:53-66.

MacKown, C.T. and T.G. Sutton. 1998. Using earlyseason leaf traits to predict nitrogen sufficiency of Burley tobacco. Agron. J. 90:21-27.

Magalhaes, J.R. and D.M. Huber. 1991. Response of ammonium assimilation enzymes to nitrogen form treatments in different plant species. J. Plant Nutr. 14:175-185.

Manrique, L. A. 1994. Nitrogen requirements of taro. J. Plant Nutr. 17:1429-1441.

Marschner, H. 1995. Mineral nutrition of higher plants. Academic, London.

Marschner, H. and V. Romheld. 1983. In-vivo measurement of root-induced $\mathrm{pH}$ changes at the soil-root interface: Effect of plant species and nitrogen source. Z. Pflanzenphysiol. 111: 241-251.

Marti, H.R. and H.A. Mills. 1991. Calcium uptake and concentration in bell pepper plants as influenced by nitrogen form and stages of development. J. Plant Nutr. 14:1177-1185.

Miyasaka, S.C. 1979. Calcium nutrition of taro [Colocasia esculenta (L.) Schott] and its possible relationship to guava seed disease. MS Thesis, Dept. Agron. Soil Sci., Univ. of Hawaii, Honolulu. 
Miyasaka, S., R.T. Checkai, D.L. Grunes, and W.A Norvell. 1988. Methods for controlling $\mathrm{pH}$ in hydroponic culture of winter wheat forage. Agron. J. 80:213-220.

Miyasaka, S.C., C.M. Webster, and N.V. Hue. 1993. Differential response of two taro cultivars to aluminum. I. Plant Growth. Commun. Soil Sci. Plant Anal. 24:1197-1211.

Nelson, D.W. and L.E. Sommers. 1972. Determination of total nitrogen in plant material. Agron. J. 65:109-112.

Neter, J., M. Kutner, C. Nachtsheim, and W. Wasserman. 1996. Applied linear statistical models. McGraw-Hill, Boston.

O’Sullivan, J.N., C.J.Asher, and F.P.C. Blamey. 1995. Diagnostic criteria for nutrition disorders of taro, p. 83-90. In: E.T. Craswell, C.J. Asher, and J.N. O'Sullivan (eds.). Mineral nutrient disorder of root crops in the South Pacific. Watson Ferfugon, Brisbane.
Osuna, F.J., S.K. De Datta, and J.M. Bonman. 1991 Nitrogen form and silicon nutrition effects on resistance to blast disease of rice. Plant Soil 135:223-231.

Rao, I.M. and N. Terry. 1989. Leaf phosphate status, photosynthesis, and carbon partitioning in sugar beet. I. Changes in growth, gas exchange, and Calvin cycle enzymes. Plant Physiol. 90: 814-819.

Raven, J.A. 1986. Biochemical disposal of excess $\mathrm{H}^{+}$ in growing plants. New Phytol. 104:175-206.

Sanchez, P. and T. Logan. 1992. Myths and science about the chemistry and fertility of soils in the tropics, p. 35-46. In: R. Lal and P. Sanchez (eds.). Myths and science of soils of the tropics. Soil Sci. Soc. Amer., Madison, Wis.

Scoggins, H. and H. Mills. 1998. Poinsettia growth, tissue nutrient concentration, and nutrient uptake as influenced by nitrogen form and stage of growth. J. Plant Nutr. 21:191-198.
Silva, J. A., D.M. Sato, P.S. Leung, G. Dantos, and J. Kuniyoshi. 1990. Response of Chinese taro to nitrogen and potassium fertilization, p. 60-70. In: Proc. Wkshp. on Taro and Plant Population, Univ. Hawaii, Honolulu.

Thomas, P.A. and J.G. Latimer. 1995. Nutrient charge, composition of media, and nitrogen form affect growth of vinca. J. Plant Nutr. 18: 2127-2134.

Traore, A. and J. Maranville. 1999. Effect of nitrate/ ammonium ratio biomass production, nitrogen accumulation, and use efficiency in sorghum of different origin. J. Plant Nutr. 22:813-825.

Wolf, B. 1974. Improvements in the azomethine$\mathrm{H}$-method for the determination of boron. Commun. Soil Sci. Plant Anal. 5:39-44.

Xu, Q.F., C.L. Tsai, and C.Y. Tsai. 1992. Interaction of potassium with the form and amount of nitrogen nutrition on growth and nitrogen uptake of maize. J. Plant Nutr. 15:23-33. 